\title{
PENERAPAN MODEL PEMBELAJARAN PROBLEM BASED LEARNING UNTUK MENINGKATKAN KETERAMPILAN SISWA DALAM MENGIKUTI PEMBELAJARAN PJOK ROLLDEPAN DAN ROLL BELAKANG
}

\author{
Mualimin $^{1)}$, Pandu Kresnapati ${ }^{2)}$, dan Yulia Ratimiasih ${ }^{3)}$ \\ ${ }^{1}$ PJKR, Universitas PGRI Semarang \\ Email: mualimin2708@gmail.com \\ ${ }^{2}$ PJKR, Universitas PGRI Semarang \\ Email: pandukresnapati@upgris.ac.id \\ ${ }^{3}$ PJKR, Universitas PGRI Semarang \\ Email: ratimiasihyulia@gmail.com
}

\begin{tabular}{l}
\hline Artikel Info \\
\hline $\begin{array}{l}\text { Koresponden penulis: } \\
\text { Mualimin } \\
\text { Email: mualimin2708@gmail.com }\end{array}$
\end{tabular}

Diterima 14 Desember 2021

Direview 18 Januari 2022

Disetujui 29 Januari 2022

Dipublikasi 31 Januari 2022

Kata Kunci:. Model Problem Based Learning, Roll Depan dan Roll Belakang, Senam lantai

Keywords

Problem Based Learning Model, Front

Roll and Back Roll, Floor exercise

\begin{abstract}
Abstrak
Tujuan penelitian ini adalah untuk mngetehui peningkatan penerapan model pembelajaran problem based learning pada pembelajaran roll denapn dan roll belakang. Penelitian ini menggunakan one group pretest-posttest design. Penelitian ini akan membandingkan pre-test dan post-test Roll Depan dan Roll Belakang dengan Model Problem Based Learning siswa SMA Islam Kedungjati dengan total sampel sebanyak 20 siswa. Berdasarkan hasil penelitian diperoleh data rata-rata pada hari pertama nilai pretetst Roll depan sebesar 48,3 sedangkan Roll belakang nilai pretest sebesar 55,65 Selain itu nilai posttest Roll depan didapatkan sebesar 81,85 sedangkan Roll belakang nilai posttest sebesar 80,20. Pada hari kedua diperoleh nilai pretetst Roll depan sebesar 48,85 sedangkan Roll belakang nilai pretest sebesar 80,20 Selain itu nilai posttest Roll depan didapatkan sebesar 80,20 sedangkan Roll belakang nilai posttest sebesar 84,05 Peningkatan persentase antara nilai pretest dan postets Roll depan pada hari pertama yaitu $69 \%$ sedangkan peningkatan persentase antara nilai pretest dan postets Roll belakang pada hari pertama yaitu 44\% Sedangkan pada hari kedua peningkatan persentase antara nilai pretest dan postets Roll depan pada yaitu $64 \%$ dan peningkatan persentase antara nilai pretest dan postets Roll belakang yaitu $45 \%$.
\end{abstract}

\begin{abstract}
This study aims to determine whether the application of the Problem Based Learning Model can improve students' skills in participating in Front Roll and Back Roll Physical Education learning. This study uses a one group pretestposttest design. This study will compare the pre-test and post-test of Front Roll and Back Roll with the Problem Based Learning Model of Kedungjati Islamic High School students with a total sample of 20 students. Based on the results of the study, the average data obtained on the first day the pretest value of the front roll was 48.3 while the rear roll pretest value was 55.65. In addition, the posttest value of the front roll was 81.85 while the rear roll posttest value was 80.20. On the second day, the front roll pretest value was 48.85 while the rear roll pretest value was 80.20. In addition, the front roll posttest value was 80.20 while the rear roll posttest value was 84.05 . The percentage increase between the pretest and posttest scores. Front roll on the first day that is $69 \%$ while the percentage increase between the pretest and post-test scores. The rear roll on the first day is $44 \%$. Meanwhile, on the second day the percentage increase between the pretest and post-test scores. The front roll is $64 \%$ and the percentage increase between the pretest and post-test scores. The rear roll is $45 \%$.
\end{abstract}




\section{PENDAHULUAN}

Pendidikan merupakan salah satu hal yang sangat penting untuk membekali peserta didik menghadapi masa depan. Sabaruddin (2016) pendidikan adalah kebutuhan nyata setiap manusia untuk menjamin kelangsungan hidupnya agar lebih bermartabat. Untuk itu proses pembelajaran yang bermakna sangat menentukan terwujudnya pendidikan yang berkualitas. Peserta didik perlu apat bimbingan, dorongan dan peluang yang memadai untuk belajar dan mempelajari halhal yang di perlukan dalam kehidupannya. Tuntutan masyarakat yang semakin besar terhadap pendidikan serta kemajuan ilmu pengetahuan dan teknologi, membuat pendidikan tidak mungkin lagi dikelola hanya dengan melalui pola tradisional. Berdasarkan Undang-undang Sistem Pendidikan Pasal 1 ayat 1 yang menyatakan bahwa: Pendidikan ialah usaha sadar buat menyiapkan peserta didik melalui kegiatan bimbingan, pedagogig, serta latihan peranannya dimasa yang akan tiba, pendidikan yang hanya menjadi sarana buat menyiapkan individu bagi kehidupan di masa depan, namun juga buat kehidupan anak masa kini yang sedang mengalami perkembangan yang menuju ke tingkat pendewasaan. Pendidikan berupaya menciptakan kondisi yang aman bagi perkembangan anak agarmampu berkembang secara optimal. Di proses pendidikan, anak aktif mengembangkan diri dan guru aktif membantu membentuk kemudahan buat perkembangan yang optimal tersebut.

Seorang pengajar dituntut mempunyai kreativitas pada mengajar senam lantai, supaya tujuan pembelajaran dapat tercapai. Oleh sebab itu, dalam mengajarkan teknik dasar senam lantai guling depan, guru wajib kreatif dalam memilih metode pembelajaran yang sempurna sebagai akibatnya peserta didik akan lebih praktis buat memahami serta melakukan teknik dasar senam lantai roll depan dan roll belakang. Pemilihan metode pembelajaran yang kurang sempurna akan menyebabkan peserta didik kesulitan pada mencapai tujuan pembelajaran. menggunakan demikian, pemilihan metode pembelajaran yang sempurna, efektif serta efisien adalah hal yang sangat krusial pada proses pembelajaran. Hasil observasi pengamatan saat pembelajaran teknik dasar senam lantai roll depan dan roll belakang di SMA Islam Sudirman Kedungjati Grobogan, penelitian menemukan banyak peserta didik yang belum mampu melakukan teknik dasar gerak roll depan dan roll belakang menggunakan baik dan benar, diduga ketika pengajar menggambarkan peserta didik kurang begitu jelas, banyak peserta didik yang ngobrol serta kurang memperhatikan posisi tangan, posisi awalan, posisi kaki, dan posisi akhir. Penjelasan yang di berikan oleh pengajar memuat secara keseluruhan rangkaian gerakan sehingga sebagian besar peserta didik kurang tau dengan baik. Hal itu itu bisa dilihat di lihat asal aktivitas peserta didik 


\section{Journal STAND: Sports and Development}

http://jurnal.unipasby.ac.id/index.php/stand/about/submissions jurnal.stand@unipasby.ac.id

yang banyak duduk, mengobrol, malas, gaduh, serta peserta didik yang banyak duduk, mengobrol, malas, gaduh serta peserta didik yang mencoba mempraktikkan materi senam lantai roll depan dan roll belakang hanya $30 \%$ jumlah peserta didik yang aktif. Hal ini bisa di artikan bahwa minat siswa terhadap materi senam lantai roll depan serta roll belakang kurang begitu antusias.

Maka dari permasalahan itu peneliti mendaptkan rumusan masalah sebagia berikut apakah Penerapan Model Pemebelajaran Problem Based Learning dapat Untuk Meningkatkan Keterampilan Siswa Dalam Mengikuti Pembelajar Penjas Roll Depan dan Roll Belakang siswa kelas XI SMA Islam Sudirman Kedungjati Grobogan?

\section{METODE PENELITIAN}

Pendekatan kuantitatif adalah metode penelitian yang berlandaskan pada filsafat positivism, diguakan untuk meneliti paada populasi atau sampel tertentu (Sugiyono, 2015: 14). Penelitian ini dilakukan dengan menggunakan pendekatan kuantitatif yang menggunakan metode eksperimen. Sugiyono (2015: 11) metode eksperimen merupakan metode penelitian yang digunakan untuk mencari pengaruh treatment (perlakuan). Metode eksperimen bertujuan untuk memperoleh data yang menyajikan dan memberikan efek yang baik terhadap suatu variabel. Hal ini dilakukan dengan cara memberikan perlakuan treatmen latihan senam lantai roll depan, roll belakan pada metode Problem Based Learning.

Desain pada penelitian eksperimen ini penelitian menggunakan metode Problem Based Learning. Bentuk penelitian ini yaitu memberikan test awal (pretest) terlebih dahulu untuk mengetahui kemampuan hasil belajar teknik dasar senam lantai roll depan, roll belakang sebelum diberikan perlakuan (treatment). Dalam perlakuan (treatment) ini akan memberikan materi senam lantai roll depan, roll belakang menggunakan metode pembelajaran, yaitu metode Problem Based Learning adapun karakteristik metode pemecahan masalah yang digunakan dalam pelakssanaan pembelajaran senam lantai roll depan, roll belakang, sebagai berikut:

1. Metode Problem Based Learning dapat menggunakan metode lainnya yang dimulai dengan mencari data sampai kepada menarik kesimpulan

2. Pembelajaran terpusat pada siswa seutuhnya, sebab dalam proses pembelajaran ini peran guru dibatasi seminim mungkin sedangkan peranan siswa diberi kebebasan semaksimal mungkin. Strategi pembelajaran penjaskes ada materi senam lantai roll depan, roll belakang menggunakan metode Problem Based Learning adalah sebagai berikut:

Tahap persiapan mempersiapkan tes mengerjakan soal untuk siswa, siswa mulai masuk ke ruangan kelas dan duduk pada kursi

Volume 2 Nomor 2 Tahun 2021 | 130 
http://jurnal.unipasby.ac.id/index.php/stand/about/submissions jurnal.stand@unipasby.ac.id

yang telah disediakan. Pelaksanaan pembagian kelompk siswa di berikan tes mengerjakan soaltentang teknik dasar senam lantai roll depan, roll belakang. Setelah selesai mengerjakan soal tes kemudian siswa mengumpulkan tugasnya, selanjutnya siswa di perlihatkan video teknik dasar roll depan, roll belakang siswa di suruh memahami tentang teknik dan cara melakukan roll depan, roll belakang dengan baik dan benar, siswa turun ke lapangan dan mempraktikkan teknik dasar roll depan, roll bekang. Kemudian guru melakukan refleksi guna untuk meluruskan pemahaman siswa dalam melakukan teknik dasar roll depan, roll belakang.

Selanjutnya melakukan tes akhir (posttest) untuk mengetahui kemampuan hasil belajar senam lantai menggunakan roll depan, roll belakang setelah diberikan perlakuan. Test yang digunakan dalam penelitian ini adalah kisi-kisi atau rubrik penilaian teknik dasar roll depan, roll belakang. Dengan demikian hasil perlakuan dapat diketahui lebih akurat, karena dapat membandingkan dengan keadaan sebelum diberi perlakuan. Gambar desain ini sebagai berikut:

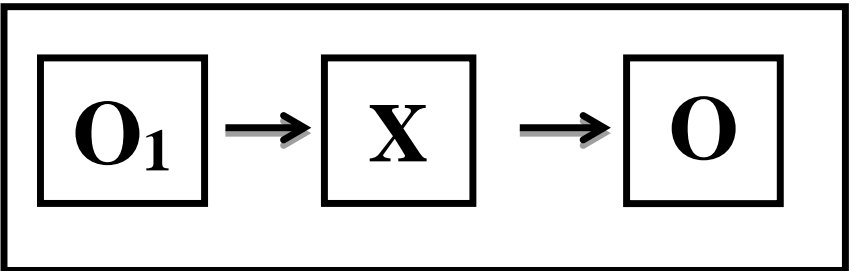

Gambar 1. One Group Pre-Test and Post-Test Experimen Design
Keterangan :

$0_{1}=$ Test awal (pretest)

$\mathrm{X}=$ Perlakuan dengan model pembelajaran

$0_{2}=$ Test akhir (posttest)

\section{HASIL DAN PEMBAHASAN}

Penelitian ini dilaksanakan di Sekolah Menengah Atas (SMA) Islam Sudirman Kedungjati Grobogan pada tanggal, 23 Agustus sampai dengan tanggal 24 Agustus 2021. Penelitian ini sebanyak 2 (dua) kali pertemuan, dengan subjek penelitian siswa kelas XI dengan jumlah siswa 20 siswa, pengambilan nilai tes roll depan dan roll belakang menggunakan butir tes dan kuisioner senam lantai dilaksanakan di lapangan bola voli SMA Islam Sudirman Kedungjati Grobogan.

Analisis data pada penelitian ini yaitu menggunakan uji normalitas dan uji hipotesis. Berikut ini merupakan hasil olah data uji hipotesis:

Tabel 1. Uji Hipotesis

\begin{tabular}{|c|c|c|c|c|c|c|c|c|c|}
\hline \multicolumn{10}{|c|}{ Paired Samples Test } \\
\hline & & \multicolumn{5}{|c|}{ Paired Differences } & \multirow[b]{3}{*}{$\mathrm{T}$} & \multirow[b]{3}{*}{ df } & \multirow{3}{*}{$\begin{array}{l}\text { Sig. (2- } \\
\text { tailed) }\end{array}$} \\
\hline & & \multirow[b]{2}{*}{ Mean } & \multirow{2}{*}{$\begin{array}{c}\text { Std. } \\
\text { Deviatio } \\
\text { n }\end{array}$} & \multirow{2}{*}{$\begin{array}{l}\text { Std. } \\
\text { Error } \\
\text { Mean }\end{array}$} & \multicolumn{2}{|c|}{$\begin{array}{l}95 \% \text { Confidence } \\
\text { Interval of the } \\
\text { Difference }\end{array}$} & & & \\
\hline & & & & & Lower & Upper & & & \\
\hline $\begin{array}{l}\text { Pair } \\
1\end{array}$ & $\begin{array}{l}\text { Pretes } \\
\text { RD 1 - } \\
\text { Postes } \\
\text { RD 1 }\end{array}$ & $\begin{array}{r}33,55 \\
0\end{array}$ & 19,848 & 4,438 & 42,839 & $-24,261$ & $-7,559$ & 19 &, 000 \\
\hline $\begin{array}{l}\text { Pair } \\
2\end{array}$ & $\begin{array}{l}\text { Pretes } \\
\text { RB 1 - } \\
\text { Postes } \\
\text { RB 1 }\end{array}$ & $\begin{array}{r}- \\
24,55 \\
0\end{array}$ & 12,886 & 2,881 & 30,581 & $-18,519$ & $-8,520$ & 19 & .000 \\
\hline $\begin{array}{l}\text { Pair } \\
3\end{array}$ & $\begin{array}{l}\text { Pretes } \\
\text { RD 2 - } \\
\text { Postes } \\
\text { RD 2 }\end{array}$ & $\begin{array}{r}31,35 \\
0\end{array}$ & 16,844 & 3,766 & $39,233^{-}$ & $-23,467$ & $-8,324$ & 19 &, 000 \\
\hline $\begin{array}{l}\text { Pair } \\
4\end{array}$ & $\begin{array}{l}\text { Pretes } \\
\text { RB 2 - } \\
\text { Postes } \\
\text { RB 2 }\end{array}$ & $\begin{array}{r}- \\
26,15 \\
0\end{array}$ & 19,521 & 4,365 & 35,286 & $-17,014$ & $-5,991$ & 19 &, 000 \\
\hline
\end{tabular}

Berdasarkan data yang didapatkan maka 
http://jurnal.unipasby.ac.id/index.php/stand/about/submissions jurnal.stand@unipasby.ac.id

pada preteest sebelumnya diberikan treatmen lewatr pembelajaran rata-rata roll depan dan roll belakang senam lantai pada kelas XI SMA Islam Sudirman Kedungjati Grobogan, diperoleh data rata-rata pada hari pertama yaitu diperoleh nilai pretetst roll depan sebesar 48,3 sedangkan roll belakang nilai pretest sebesar 55,65 Selain itu nilai posttest roll depan didapatkan sebesar 81,85 sedangkan roll belakang nilai posttest sebesar 80,20 . Pada hari kedua diperoleh nilai pretetst roll depan sebesar 48,85 sedangkan roll belakang nilai pretest sebesar 80,20 Selain itu nilai posttest roll depan didapatkan sebesar 80,20 sedangkan roll belakang nilai posttest sebesar 84,05 Peningkatan persentase antara nilai pretest dan postets roll depan pada hari pertama yaitu $69 \%$ sedangkan peningkatan persentase antara nilai pretest dan postets roll belakang pada hari pertama yaitu $44 \%$ Sedangkan pada hari kedua peningkatan persentase antara nilai pretest dan postets roll depan pada yaitu 64\% dan peningkatan persentase antara nilai pretest dan postets roll belakang yaitu $45 \%$.

Peningkatan hasil belajar roll depan dan roll belakang merupaakan pengaruuhi daari prosees pembeelajaran dengan menggunakan model problem based learning. Dilihat dari hasil pengolhan daat melaui analisiis statistiik dapt dilihat bahwa setelaah membaandingkan antara pretestt dan postteest sebagian bessar hasiil yang dipeeroleh peserta didik mengallami peningkatan. Haal ini tentunnya tidak leepas dari penngaruh model pembelajaran Problemm Based Learning dengan peserta didik memeccahkan maasalah pembelajaran secara berkelompok yang telah diberikan oleh gurunya. Banyaak kondiisi terjaadi dilaapangan yagn meiliki pengaruh terhadap peningkatan peserta didik seperrti semangat mereka dalaam mengikuuti pembeelajaran, selain itu juga siikap disiplini mereeka sanggat mmeberikan damapak pada hasil beelajar yagn ada, proses keaktiifan peserta didik dallam aktivvitas belaajar dan antusiias peserta didik daalam mengikuuti kegiiatan sangat memberikan damppak positif terrhadap perkembaangan diirinya.

Berlandaskan keberrhasilan pembelajaran tersebut tenntu saja dapat menjadii sebuah fakktor pendorong dalam tercapainya tujuaan pembellajaran secaara maksiimal yagn terjjadi disekoolah, sehingga dengan keberhasilan pemmbelajaran tersebut para peserta diidik kaan dapat memaksimallkan dirinnya sendiri dalam meningkatkan prestasii yang aada, baiik prestasi belajar atau preestasi olahraga disekoolah maupun di luaar sekollah.

\section{SIMPULAN DAN SARAN}

Berdasarkan dari dataa yang telah diambil model Problem Based Learning baik preteest dan posttestt sebagai hasil dari penelitiaan, maka didapatkan bahwa paada pretest sebelumm diberikan treatmenn melaliu prooses pembelajaran rata-rata hasil pembelaajaran roll depan dan roll belakang 
http://jurnal.unipasby.ac.id/index.php/stand/about/submissions jurnal.stand@unipasby.ac.id

senam lantai kelas XI SMA Islam Sudirman Kedungjati Grobogan, yaitu diperoleh data rata-rata pada hari pertama nilai pretetst roll depan sebesar 48,3 sedangkan roll belakang nilai pretest sebesar 55,65 Selain itu nilai posttest roll depan didapatkan sebesar 81,85 sedangkan roll belakang nilai posttest sebesar 80,20 . Pada hari kedua diperoleh nilai pretetst roll depan sebesar 48,85 sedangkan roll belakang nilai pretest sebesar 80,20 Selain itu nilai posttest roll depan didapatkan sebesar 80,20 sedangkan roll belakang nilai posttest sebesar 84,05 Peningkatan persentase antara nilai pretest dan postets roll depan pada hari pertama yaitu 69\% sedangkan peningkatan persentase antara nilai pretest dan postets roll belakang pada hari pertama yaitu $44 \%$ Sedangkan pada hari kedua peningkatan persentase antara nilai pretest dan postets roll depan pada yaitu 64\% dan peningkatan persentase antara nilai pretest dan postets roll belakang yaitu $45 \%$.

\section{DAFTAR PUSTAKA}

Faturrohman.2015. Model-model pembelajaran inovatif. Jogjakarta: ARRUZZ MEDIA.

Rosmalasari, Santi. (2014). Penggunaan Model Pembelajaran Problem Based Learning (PBL) Berbantu Media Audio Visual Dalam Meningkatkan
Kemampuan Kognitif Siswa. Skripsi.

Bandung: Universitas Pasundan.

Rusman. (2013). Model-model Pembelajaran

Mengembangkan Profesionalisme Guru.

Jakarta: PT. Raja Grafindo Perseda

Sabaruddin yunis bangun, 2016.

"Pengembangan Pengetahuan Anak

Difabel Melalui Pendidikan Jasmani

Olahraga dan Outbound". Journal

Physical Education, Health and

Recreation, Volume: 1, Edisi: 1: 70-77.

Setiawan, Dkk.2020. Model-model

pembelajaran dalam pendidikan jasmnai.

Bandung: ALFABETA,cv.

Sugiyono. (2016). Metode Penelitian

Pendidikan. Bandung: Alfabeta

Sugiyono. 2017. Metode Penelitian

Pendidikan Kuantitatif, Kualitatif dan

$R \& D$. Bandung: Alfabeta.

Syahrin, A., Amiruddin., Bustaman. 2017.

"Peran Guru Pendidikan Jasmani Dalam

Membentuk Karakter Siswa Pada MTS

Se-Banda Aceh Tahun Pelajaran

2016/2017”. Jurnal Ilmiah Mahasiswa

Pendidikan Jasmani, Kesehatan dan

Rekreasi. 3 (2) 77.

Utama, A. M. B. 2011. "Pembentukan

Karakter Anak Melalui Aktivitas

Bermain Dalam Pendidikan Jasmani”.

Jurnal Pendidikan Indonesia. 8 (1) 1-2. 